\title{
Now Disease Reports \\ First record of dieback and decline of plum caused by Neoscytalidium dimidiatum in Tunisia
}

\author{
M.R. Hajlaoui ${ }^{1}{ }^{*}$, M.T. Nouri ${ }^{2}$, N. Hamrouni ${ }^{1}$, F.P. Trouillas $^{2}$, N. Ben Yahmed ${ }^{3}$, J. Eddouzi ${ }^{1,3}$ and M. Mnari-Hattab ${ }^{1}$ \\ ${ }^{1}$ Laboratoire de Biotechnologie Appliquée à I'Agriculture, INRA Tunisie, Université de Carthage, El Menzah, 1004, Tunis, \\ Tunisia; ${ }^{2}$ Department of Plant Pathology, University of California-Davis, Kearney Agricultural Research and Extension \\ Center, Parlier 93648, California, USA.; ${ }^{3}$ Sogepros-enzymax36 Laboratoire, Centre Commercial Hadika II 2042 Tunis, \\ Tunisia
}

*E-mail: hajlaoui06@gmail.com

Received: 27 Aug 2018. Published: 12 Nov 2018.

In late summer 2017, a serious decline and dieback of plum trees was observed in many orchards in Tunisia. Black Star and Sun Gold were the varieties most affected, with an incidence of up to $20 \%$. Symptoms include shoot blight with scorching of leaves, branch wilt, decline and death of trees. Cross-sections of the branches of infected trees showed necrosis and brown vascular discoloration of the wood (Fig. 1).

Necrotic wood was surface disinfected $(1 \% \mathrm{NaCl}$ for two minutes, $75 \%$ ethanol for 30 seconds) and small pieces (4 to $5 \mathrm{~mm}$ ) of necrotic tissues were surface sterilised for one minute in $1.5 \% \mathrm{NaCl}$, washed twice with sterile distilled water, and plated onto oatmeal agar (OMA) and incubated at $25^{\circ} \mathrm{C}$. After seven days, the surface of necrotic wood was colonised by a white mycelium (Fig. 2). A pure culture was obtained by single spore isolation. The fungus obtained was initially white with dense and hairy aerial mycelium that gradually turned dark grey to olive green (Fig. 3). The arthroconidia were dark brown, thick-walled, and one-celled, 6.3 to $14.2 \times$ 2 to $4.5 \mu \mathrm{m}$, and ovate to rectangular. Based on morphological characteristics, all isolates were identified tentatively as Neoscytalidium-like species (Phillips et al., 2013). The identity of the isolated fungus was confirmed by PCR amplification of the internal transcribed spacer (ITS) region using the ITS1/ITS4 primers (White et al., 1990). Based on a BLASTn search, the isolate showed $99 \%$ sequence identity with an isolate of $N$. dimidiatum that caused shoot blight, canker, and gummosis on almond (GenBank Accession No. MG021578). DNA sequences were deposited in GenBank (MH676062).

Pathogenicity tests were conducted with mycelial plugs of isolate MRHf 1 on one- to two-year-old branches of plum plants cv. Black Star. Ten branches were wounded between two nodes using a sterilised scalpel. Mycelial plugs from the margins of actively growing colonies were placed in the wounds and wrapped with paraffin film. Non-colonised OMA plugs were used as controls. Inoculated and control plants were maintained in the greenhouse at $25^{\circ} \mathrm{C}$ and high humidity for 20 days, after which the bark was peeled off and lesions were observed upward and downward from the inoculation point. All inoculated branches showed necrotic lesions (Fig. 4). No symptoms were observed in the control branches. The pathogen was reisolated from all inoculated branches and identified by conidial morphology, fulfilling Koch's postulates.

Neoscytalidium dimidiatum has been reported from a diversity of woody plants around the world causing canker and gummosis on citrus in Italy (Polizzi et al., 2009) and canker, shoot blight, and fruit rot on almond in California (Nouri et al., 2018). To our knowledge, this is the first report of $N$. dimidiatum causing plum dieback and decline in Tunisia.

\section{References}

Nouri MT, Lawrence DP, Yaghmour MA, Michailides TJ, Trouillas FP, 2018. Neoscytalidium dimidiatum causing canker, shoot blight and fruit ro of almond in California. Plant Disease 102, 1638-1647.

http://dx.doi.org/10.1094/PDIS-12-17-1967-RE

Phillips AJL, Alves A, Abdollah Zadeh A, Slippers B, Wingfield MJ, Groenewald JZ, Crous PW, 2013. The Botryosphaeriaceae: genera and species known from culture. Studies in Mycology 76, 51-167. http://dx.doi.org/10.3114/sim0021

Polizzi G, Aiello D, Vitale A, Giuffrida F, Groenewald JZ, Crous PW, 2009. First report of shoot blight, canker, and gummosis caused by Neoscytalidium dimidiatum on citrus in Italy. Plant Disease 93, 1215. http://dx.doi.org/10.1094/PDIS-93-11-1215A

White TJ, Bruns T, Lee S, Taylor JW, 1990. Amplification and direct sequencing of fungal ribosomal RNA genes for phylogenetics. In: Innis MA, Gelfand DH, Sninsky JJ, White TJ, eds. PCR Protocols: A Guide to Methods and Applications. New York, USA: Academic Press Inc., 315-322. http://dx.doi.org/10.1016/B978-0-12-372180-8.50042-1

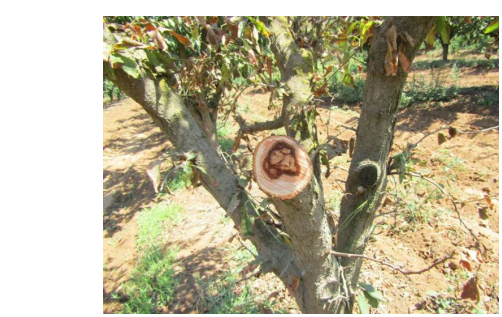

Figure 1

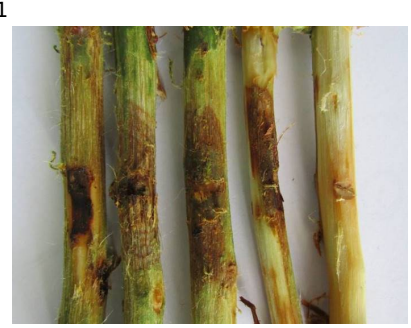

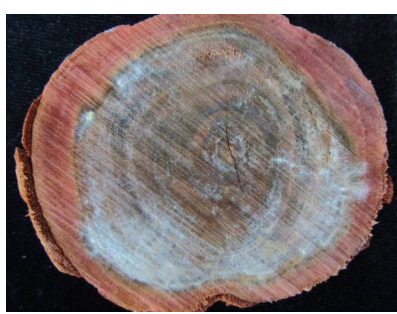

Figure 2

Figure 3

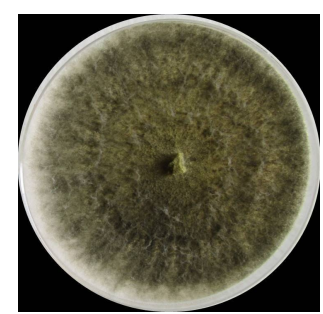

Figure 4

To cite this report: Hajlaoui MR, Nouri MT, Hamrouni N, Trouillas FP, Ben Yahmed N, Eddouzi J, Mnari-Hattab M, 2018. First record of dieback and decline of plum caused by Neoscytalidium dimidiatum in Tunisia. New Disease Reports 38, 20.

http://dx.doi.org/10.5197/j.2044-0588.2018.038.020

(c) 2018 The Authors

This report was published on-line at www.ndrs.org.uk where high quality versions of the figures can be found.

New Disease Reports is a peer-reviewed on-line journal published by the British Society for Plant Pathology,

for more information visit http://www.ndrs.org.uk/ 